\title{
Quality of Nursing Worklife Based on Caring Model for Improving Nurse Performance in Hospitals
}

Indonesian Nursing Journal of Education and Clinic (INJEC)

172-184

Volume 5, Issue 2, December 2020

DOI: 10.24990/injec.v5i2.339

injec.aipni-ainec.org/index.php/INJEC/index

Received : 2020-09-09

Accepted : 2020-09-16

The Association of Indonesian Nurse Education Center (AINEC)

\author{
Dluha Mafula' ${ }^{(1)}$, Nursalam Nursalam ${ }^{1}$, Tintin Sukartini '
}

\begin{abstract}
Introduction: Nurses performance is still not optimal. The aim this study was to develop a quality of nursing work life to improve nurse performance by integrating Swanson's theory of caring.

Methods: An explanative observational design was used with cross-sectional approach. The sample was nurses in inpatient care, intensive care, surgical installations, neonates, hemodialysis from eight hospitals in East Java. The sample size of 430 respondents used total sampling. The variables included QNWL, individual, social and environmental, administrative factors, nurse performance. Data were collected using Nurse Quality of Communication with Patient Questionnaire (NQCPQ), Questionnaire of Personal and Organizational Values Congruence for Employee (Q-POVC), Questionnaire of Brooks \& Anderson's quality of nursing work life. The data analysis used Partial Least Square.

Results: Twenty-five indicators were declared valid (outer loading value $>0.5$ ) with variable diversity was $24.43 \%$, so that internal, social and environmental, operational and administrative factors affect the performance of nurses directly or indirectly through caring based on QNWL. Predictive relevance value was $>0$, which indicates that the model was good enough. The individual factors $(p=0.043 ; T$ Statistics= 2.040), social and environment factors $(p=0.025 ; T=2.242)$, administrative factors $(p=$ $0.00 \mathrm{I}$; T= 3.438) have significant influence $\mathrm{QNWL}$ based on caring and QNWL based on caring had a significant influence on nurse performance $(P=0.000 ; T=4.997)$.

Conclusion: The development of the QNWL model based on caring has good effect in improving nurse performance. From the developed model, nurse performance related to individual factors, social and environmental factors, administrative factors.
\end{abstract}

\section{Keywords}

caring; nurse performance; quality of nursing work life

\section{INTRODUCTION}

The quality and the quality of the nurse when performing nursing care are still not optimal. Work overload, the lack of professional opportunities such as education and training have an impact on the low quality of nursing work life (Nursalam, Fibriansari, et al., 2018b; Oshodi et al., 2019). Additionally, the patient's complaints, dissatisfaction, and refusal to tell the problem means nurses have

\footnotetext{
' Faculty of Nursing Universitas Airlangga, Surabaya, Indonesia
} 
a duty to serve patients better (Amalina, Rachmawaty, Ilkafah, \& Erfina, 2020). This causes a decrease in nurses' performance. The caring aspect must be applied in the selfdevelopment of nurses to improve the work environment, especially with patients, to achieve organizational goals.

In Oramia Hospitals in Southwest Ethiopia, nurses cannot apply caring aspects well $(30 \%)$, and $50 \%$ of patients stated the elements of concern inclined to the poor (Oluma \& Abadiga, 2020). Most nurses from an Acute National Health Service Trust only apply the caring principle to expressive aspects, such as listening to patient complaints but without empathy, while the monitoring aspect is not carried out correctly (Chana, Kennedy, \& Chessell, 2015; Oluma \& Abadiga, 2020). The quality of nursing work life has also decreased, as much as $32.6 \%$ of nurses are paid a low rate of the salaried sector, and working hours are not suitable. These results affect incomplete nursing care; nurses think that the performance given is commensurate with the salary given, even though not all tasks are complete (Momeni, Shafipour, Esmaeili, \& Yazdani Charati, 20I6; Suleiman, Hijazi, Al Kalaldeh, \& Sharour, 2019).

Factors affecting nurse performance are motivation, work rotation rewards and punishment. The hospital management needs to improve the motivation of nurses by holding regular meetings to improve interpersonal relationships and giving stimulus for nurses' career program (Gunawan, Hariyati, \& Gayatri, 2019; Terzioglu, Temel, \& Uslu Sahan, 2016). Referring to the improvement and maintenance of nurse performance, a guiding framework uses Swanson's caring behaviors. Caring is an action based on affection, skill, empathy, responsibility, sensitivity, and support. Rewards by patients are needed for nurses in their work environment as an acknowledgment (Chana et al., 2015; Loke and Lee, 2020; Oluma \& Abadiga, 2020; Rawnak, 2020). Caring is needed to solve these problems (Viselita, Handiyani, \& Pujasari, 2019). On the other hand, as a nurse, caring professionalism should be a characteristic of nurses in every action, and this can be used as innovations to help complement the quality of nursing work life to achieve better work output.

Nurses should try to provide impersonal care for patients through their work life so that they have higher quality. Previous research has shown that quality of nursing work-life can improve the performance of nurses, but there is no development of the QNWL model; therefore, this study is interested in developing QNWL by integrating it with Swanson's caring theory. The quality of the nursing work-life has not yet discussed the attitudes and relationships of nurses with patients where good relationships, such as understanding, the presence of nurses physically and psychologically (empathy), helping, providing support, and trust can increase the commitment and responsibility of a nurse. Based on the explanation above, the aim of the study was to develop a QNWL model to improve nurse performance by integrating Swanson's theory of caring which has five elements, namely, maintaining belief, knowing, being with, doing for, and enabling.

\section{MATERIALS AND METHODS}

Study design

An explanative observational research with a cross-sectional approach was used to this study.

\section{Sample}

The population in this study was nurses in inpatient care, intensive care, surgical installations, neonates, hemodialysis from eight hospitals in East Java. The sample size of 430 respondents used total sampling. The inclusion criteria were: (a) Nurses who have worked for at least one year, (b) minimum education diploma. The exclusion criteria were: the nurse was on leave, nurses who were in study permits, or assignments. 
Table I. Research Variable QNWL Model to Improve Nurse Performance by Integrating Swanson's Theory of Caring

\begin{tabular}{|c|c|c|}
\hline Variables & Information & Indicators \\
\hline \multirow[t]{7}{*}{$\mathrm{X} 1$} & Individual factor & X1.1 Age \\
\hline & & X1.2 Sex \\
\hline & & X1.3 Marital \\
\hline & & X1.4 Education \\
\hline & & X1.5 Clinical level \\
\hline & & X1.6 Length of work \\
\hline & & X1.7 Income \\
\hline \multirow[t]{6}{*}{$\mathrm{X} 2$} & Social and environmental factors & X2.1 Communication \\
\hline & & X2.2 Leadership \\
\hline & & X2.3 Relationships between nurses \\
\hline & & X2.4 Relationships between departments \\
\hline & & X2.5 Relationships between professions \\
\hline & & X2.6 Environment \\
\hline \multirow[t]{3}{*}{ X3 } & Administrative factors & X3.1 Organizational policies \\
\hline & & X3.2 Occupational health \\
\hline & & X3.3 Safety and salaries \\
\hline \multirow[t]{6}{*}{$\mathrm{X} 4$} & QNWL based on caring & X4.1 Work life-home life (maintaining belief, \\
\hline & & knowing, being with, doing for, and enabling) \\
\hline & & X4.2 Work design (maintaining belief, knowing, \\
\hline & & being with, doing for, and enabling) \\
\hline & & $\begin{array}{l}\text { X4.3 Work content (maintaining belief, knowing, } \\
\text { being with, doing for, and enabling) }\end{array}$ \\
\hline & & X4.4 Work world (maintaining belief, knowing, \\
\hline \multirow{2}{*}{ Y1 } & Nurce nerffrmanco & being with, doing for, and \\
\hline & & Y1. 2 Quantity of work \\
\hline
\end{tabular}

informed consent form. Furthermore, they

\section{Variables}

The independent variables were individual factor (age, sex, marital, education, clinical level, length of working, income), social and environmental factors (communication, leadership, and relationships between nurses, between departments, between professions, environment), administrative factors (organizational policies, occupational health and safety and salaries), QNWL based on caring (work life-home life, work design, work content, work world involving maintaining belief, knowing, being with, doing for, and enabling). The dependent variable (YI) in this study was the nurse performance (quality and quantity of work) (Table I).

\section{Setting and locations}

The study was conducted between June and August 2020 in hospitals in East Java, Indonesia. The researchers introduced themselves and explained the benefits, goals, and approval procedures by referring to the gave questionnaires to respondents regarding any individual factor (age, sex, marital, education, clinical level, length of work, income), social and environmental factors (communication, leadership, and relationships between nurses, between departments, between professions, environment) and administrative factors (organizational policies, occupational health and safety, and salaries), QNWL based on caring (work-life-home life, work design, work content, work world, involving maintaining belief, knowing, being with, doing for, and enabling) and nurse performance (quality and quantity of work). The data collection was carried out by online using Google Forms.

\section{Instrument and Measurement}

Demographic factors consisted of age, sex, marital, education, clinical level, length of work, employment status, and income. The nurses' age was divided into four categories based on Indonesian age categories (Department of Health of Republic, Indonesia, 2009). The nurses' 
education was divided into four categories based on the constitution of the Republic of Indonesia, namely: magister, profession, bachelor, and diploma (Higher Education Law No. 12 of 2012). Career path was divided into five categories based on Competency-Based Continuing Education (Certification) and was categorized into Level I, Level 2, Level 3 (Regulation of the Minister of Health Number 40 of 2017 and Regulation of the Minister of Health Number 49 of 2013 concerning the Nursing Committee).

Nurse communication with patients was measured using a modified Nurse Quality of Communication with Patient Questionnaire (NQCPQ) questionnaire (Vuković, Gvozdenović, Stamatović-gajić, Ilić, \& Gajić, 2010). The questionnaire consisted of 13 questions with measurements using a Likert scale $0=$ never, $\mathrm{I}=$ rarely, 2 = sometimes, 3 = often, 4 = always. The questionnaire used an ordinal scale with the following scoring: 3 $=$ Good (76\%-100\%), $2=$ Moderate $(56 \%-$ $75 \%$ ) and $\mathrm{I}=$ Less (<56\%). Relationships between nurses, department, and professions were measured using a modified Environment Scale of the Nursing Work Index (PES-NWI) questionnaire (Ferreira \& Martins, 20I4). The questionnaires on relationships between nurses, department, and professions consisted of 5, 6 and 6 questions, respectively, with measurements using a Likert scale of $0=$ never, $1=$ rarely, $2=$ sometimes, 3 = often, $4=$ always. The questionnaire used an ordinal scale with the following scoring: $3=$ Good (76\%$100 \%), 2=$ Moderate $(56 \%-75 \%)$ and $\mathrm{I}=$ Less $(<56 \%)$.

The organizational policy was measured using a modified Questionnaire of Personal and Organizational Values Congruence for Employee (Q-POVC) questionnaire (Vveinhardt \& Gulbovaite, 2017). The questionnaire consists of 13 questions using categories $0=$ no, $I=$ yes and uses an ordinal scale with the following scoring: $3=$ Good (76\%-100\%), $2=$ Moderate $(56 \%-75 \%)$ and $\mathrm{I}=$ Less $(<56 \%)$. QNWL was measured using QNWL Brooks \& Anderson's quality of nursing work life, modified by the researchers. This scale has 42 items, and it has four subscales that focus on home life or work life (7 items), work organization or design (10 things), work conditions or contention (20 items), and work world (5 items). It was scored on a six-point Likert scale in terms of strongly disagree, moderately disagree, disagree, agree, moderately agree, strongly agree. The score on each item was summed up to obtain the total score. The subscale scores were accepted by summing up the score obtained in the subscales. The minimum total score was 42 , and the maximum score was 252 . The scores were interpreted as 42-84: low quality of work life, 85-168: moderate quality of work life, 169-252: high quality of work life. The instrument for nurse performance was made by the researchers based on the indicators of quality and quantity of nurse work. The questionnaire contained fourteen questions and used an ordinal scale with the following scoring: $3=$ Good (76\% - 100\%), 2 = Moderate $(56 \%-75 \%)$, I $=$ Less $(<56 \%)$.

\section{Data analysis}

Statistical analyses were performed using SEM PLS. Descriptive statistics, such as numbers, percentages, mean and standard deviation, were used to present the descriptive characteristics of the respondents. This study used a structural equation modelling model based on variance or component-based called PLS (Partial Least Squares). The model evaluation consisted of two parts, namely the evaluation of the outer model with the relative indicators evaluated based on the results of the validity and reliability indicators. Convergent validity was the correlation between the reflective indicator scores and the latent variable scores. A factor loading value of 0.5 to 0.6 
states that the indicator was valid. Discriminant validity was the value of the cross-loading correlation with the latent variable, which must be higher than the correlation with other potential variables. The average variance extracted (AVE) value must be above 0.5 , and the composite reliability value is good if it has a value of $\geq$ 0.7. The evaluation of the inner model was done in order to determine the magnitude of the influence or causal relationship between the variables in the study, namely by getting the value of $R$ square (coefficient of determination) and the value of Q2 (relevance of prediction). $\mathrm{R}$ square is a value that explains the amount of influence of the independent variables on the dependent variable. If the $\mathrm{Q} 2$ value is more than two and close to I, then the model is proven to have predictive relevance. If the Q2 value is below zero, then the model has no predictive relevance.

\section{Ethical Considerations}

The Ethical Commission approved this study in Faculty of Nursing Universitas
Airlangga, East Java, Surabaya, Indonesia, with No. 207I-KEPK on August 4th, 2020. Written consent was obtained from all centers. The aim of the study was explained to the participants, and informed consent forms were collected.

\section{RESULTS}

The majority of respondents aged 26-35 years old were female, had completed a professional education (52.8\%). The majority of nurses $(76.3 \%)$ were married, had worked for five years with income> $5,000,000$. The average length of work for nurses was around five years and above with a clinical level at level 2 as much as $40 \% \%$ (Table 2).

Most of the respondents stated that communication with patients was good enough (63.72\%)-leadership style was in the good category (53.02\%). The relationship between nurses, departments, and professions was also good. Nurses stated that they have a high level of workload, but the shift schedule was in a good category and had high flexibility (66.05\%). The supervisory role of the head of the room was also going well. From the aspect of organizational policy $(59.53 \%)$ and salary $(60 \%)$,

Table 2. Distribution of Respondent Characteristics $(n=430)$

\begin{tabular}{llcc}
\hline \multicolumn{1}{c}{ Characteristics } & Category & n & \% \\
\hline \multirow{4}{*}{ Age } & $17-25$ & 152 & 35.3 \\
& $26-35$ & 157 & 36.5 \\
Gender & $36-45$ & 102 & 23.7 \\
& $46-55$ & 19 & 4.4 \\
Marital status & Male & 153 & 35.6 \\
& Female & 277 & 64.4 \\
Latest Education & Single & 98 & 22.8 \\
& Married & 328 & 76.3 \\
& Divorced & 4 & 0.9 \\
Clinical level (career path) & Diploma & 168 & 39.1 \\
& Professional & 227 & 52.8 \\
& Magister & 35 & 8 \\
Length of work & Pra clinic & 44 & 10.2 \\
& Level 1 & 105 & 24.4 \\
& Level 2 & 172 & 40.0 \\
& Level 3 & 109 & 25.3 \\
Income & $1-2$ year & 79 & 18.4 \\
& $3-4$ year & 49 & 11.4 \\
& 5 year & 302 & 70.2 \\
& $<1.000 .000$ & 5 & 1.2 \\
& $1.000 .000-<2.000 .000$ & 68 & 15.8 \\
& $2.000 .000-<3.000 .000$ & 81 & 18.8 \\
& $3.000 .000-<4.000 .000$ & 81 & 18.8 \\
& $4.000 .000-<5.000 .000$ & 97 & 22.6 \\
& $>5.000 .000$ & 98 & 22.8 \\
\hline
\end{tabular}


Table 3. Variable Identification of Model Development

\begin{tabular}{|c|c|c|c|c|c|c|}
\hline \multirow{3}{*}{ Variables } & \multicolumn{6}{|c|}{ Category } \\
\hline & \multicolumn{2}{|c|}{ Good } & \multicolumn{2}{|c|}{ Adequate } & \multicolumn{2}{|c|}{ Inadequate } \\
\hline & $\mathbf{N}$ & $\%$ & $\mathbf{N}$ & $\%$ & $\mathbf{N}$ & $\%$ \\
\hline \multicolumn{7}{|l|}{ Social and environmental factors } \\
\hline Communication & 274 & 63.72 & 124 & 28.84 & 32 & 7.44 \\
\hline Leadership & 228 & 53.02 & 150 & 34.88 & 52 & 12.09 \\
\hline Relationships between nurses & 226 & 52.56 & 133 & 30.93 & 71 & 16.51 \\
\hline Relationships between departments & 287 & 66.74 & 111 & 25.81 & 32 & 7.44 \\
\hline Relationships between professions & 375 & 87.21 & 49 & 11.40 & 6 & 1.4 \\
\hline Environment & 284 & 66.05 & 102 & 23.72 & 44 & 10.23 \\
\hline \multicolumn{7}{|l|}{ Administrative factors } \\
\hline Organizational policies & 256 & 59.53 & 66 & 15.35 & 108 & 25.12 \\
\hline Occupational health & 50 & 11.63 & 290 & 67.44 & 90 & 20.93 \\
\hline Safety and salaries & 258 & 60 & 158 & 36.74 & 14 & 3.26 \\
\hline \multicolumn{7}{|l|}{ QNWL based on caring } \\
\hline $\begin{array}{l}\text { Work life-home life } \\
\text { (maintaining belief, knowing, being with, doing for, } \\
\text { and enabling) }\end{array}$ & 302 & 70.23 & 102 & 23.72 & 26 & 6.05 \\
\hline $\begin{array}{l}\text { Work design } \\
\text { (maintaining belief, knowing, being with, doing for, } \\
\text { and enabling) }\end{array}$ & 236 & 54.88 & 150 & 34.88 & 44 & 10.23 \\
\hline $\begin{array}{l}\text { Work content } \\
\text { (maintaining belief, knowing, being with, doing for, } \\
\text { and enabling) }\end{array}$ & 347 & 80.70 & 77 & 17.91 & 6 & 1.4 \\
\hline $\begin{array}{l}\text { Work world } \\
\text { (maintaining belief, knowing, being with, doing for, } \\
\text { and enabling) }\end{array}$ & 236 & 54.88 & 163 & 37.91 & 31 & 7.21 \\
\hline \multicolumn{7}{|l|}{ Nurse performance } \\
\hline Quality of work & 219 & 50.93 & 200 & 46.51 & 11 & 2.56 \\
\hline Quantity of work & 404 & 93.95 & 23 & 5.35 & 3 & 0.7 \\
\hline
\end{tabular}

Table 4. Results of the Statistical Hypothesis Testing Model Development

\begin{tabular}{lcccc}
\hline \multicolumn{1}{c}{ Variable } & Path coefficients & t & p & Significance \\
\hline $\begin{array}{l}\text { individual factors }(X 1) \longrightarrow \text { QNWL-based caring } \\
\text { (X4) }\end{array}$ & 0.094 & 2.040 & 0.042 & Significant \\
social and environmental (X2) $\rightarrow$ QNWL-based & 0.139 & & & Significant \\
caring (X4) & & 2.242 & 0.025 & \\
administrative (X3) $\longrightarrow$ QNWL based caring (X4) & 0.272 & 3.438 & 0.001 & Significant \\
QNWL-based caring (X4) $\longrightarrow$ nurse performance & 0.290 & 4.997 & 0.000 & Significant \\
\hline
\end{tabular}

some respondents said it was good, but for occupational health was adequate (67.44\%). The mean total score of the QNWL in this study revealed that participants were, on average, experiencing good QNWL both dimensions work life-home life (maintaining belief, knowing, being with, doing for, and enabling), work design (maintaining belief, knowing, being with, doing for, and enabling), and work content (maintaining belief, knowing, being with, doing for, and enabling), work world (maintaining belief, knowing, being with, doing for, and enabling) (Table 3).

Figure I describes the results of the analysis of nurse performance on QNWL based on the caring model. The outer model was evaluated by measurement of the validity and reliability. Convergent validity was determined using loading factors and the average variance value extracted (AVE). Measurements can be categorized as having convergent validity and reliability if the loading factor value $>0.5$ and AVE value $>0.5$. Based on the research results, it can be seen that three indicators were invalid (outer loading value was $<0.5$ ), and these must be removed from the model.

Evaluation of inner models was used to test the research hypotheses. The research hypothesis can be accepted if the value of $T$ count $>\mathrm{T}$ table. As shown in Figure I, the individual factors, social and environmental and administrative factors have a significant influence on QNWL based on caring $(T>1.96)$. The results of the hypothesis test were described as follows: (I) individual factor (age, 


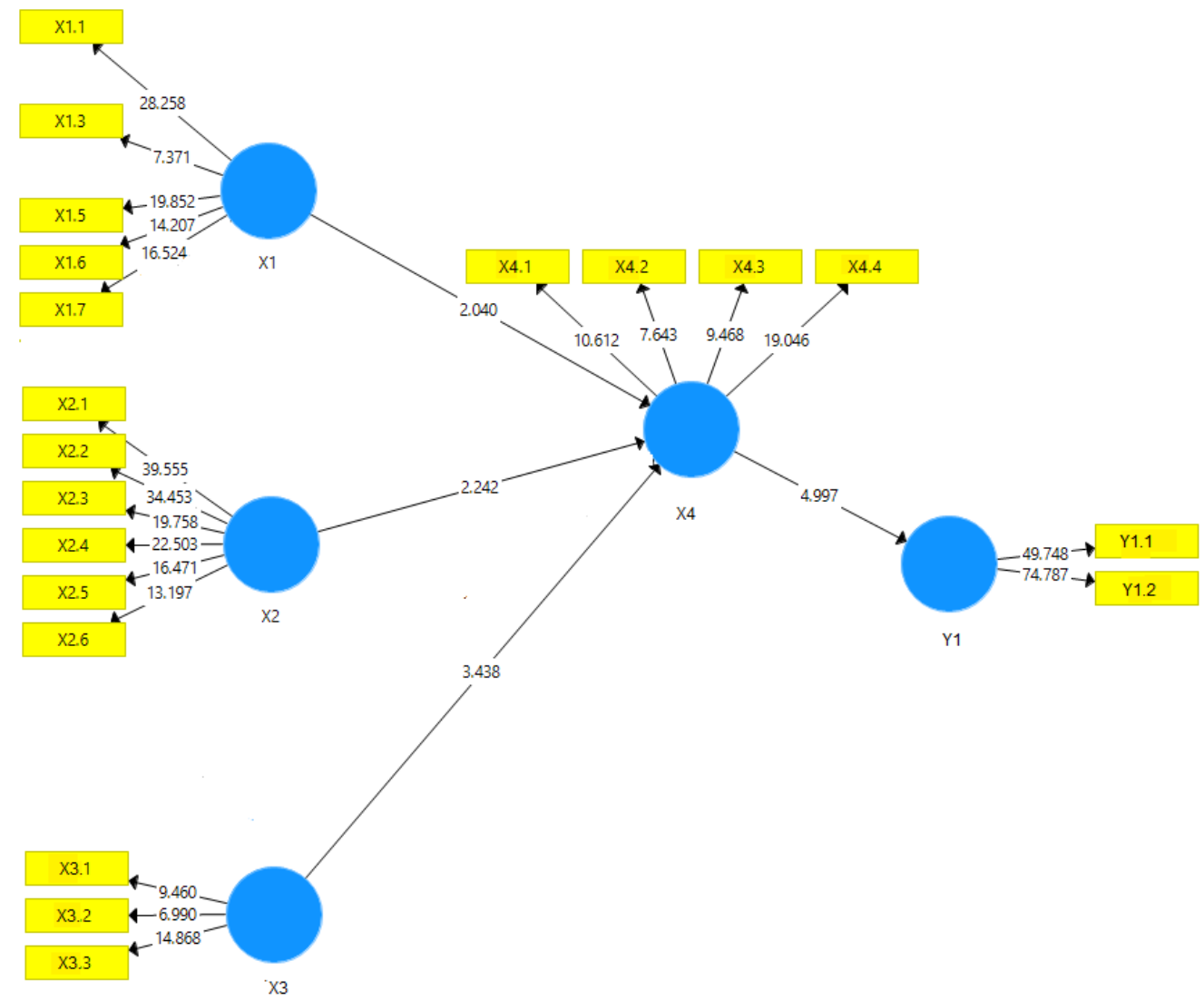

Fig. I Structure Model

sex, marital, education, clinical level, length of work, income); (2) social and environmental factors (communication, leadership, and relationships between nurses, between departments, between professions, environment); (3) administrative factors (organizational policies, occupational health and safety, and salaries); (4) QNWL based on caring (work life-home life, work design, work content, work world involving maintaining belief, knowing, being with, doing for, and enabling); (5) nurse performance (quality and quantity of work) (Table 3). The evaluation of developing QNWL based on caring was influenced by individual, social and environmental and administrative factors. Three latent variables impacted QNWL based on caring and influenced nurse performance. The novelty of this model was QNWL based on caring; there were some components of the Swanson's Theory of Caring that were compared with the QNWL dimension.

The results of the hypothesis test of the developed QNWL-based caring model for improving nurse performance are presented in Table 4. Based on Table 4, four hypotheses were obtained as follows: (I) there was a significant effect of individual factors $(X I)$ on QNWL-based caring (X4), which means that the better the individual factors, the more likely it was to increase the QNWL-based caring; (2) there was a significant social and environmental (X2) influence on QNWLbased caring (X4), which means that the better social and environmental trends to increase QNWL-based caring; (3) there was a significant administrative $(X 3)$ effect on QNWL-based caring (X4); (4) there was a significant effect of QNWL-based caring (X4) on nurse performance $(\mathrm{YI})$. The individual factors, social and environment factors, administrative factors and QNWL-based on caring have a significant influence on nurse performance $(T>1.96)$.

\section{DISCUSSIONS}

QNWL is important for nurses in carrying out their duties and jobs; a good work life can have a positive impact on nurse performance (Kelbiso, Belay, \& Woldie, 2017). Nurses who integrate caring behavior in the nursing process create beliefs in behavior where the nurse 
responds to what the patient feels and believes that these feelings can naturally occur to anyone who is in transition, offering a hopefilled attitude, helping to find meaning, avoiding assumptions, assessing thoroughly, seeking clues, centering on the one cared for, engaging the self of both, non-burdening, converting availability, enduring with, sharing feelings, comforting, performing competently, preserving dignity, protecting, informing, and supporting (Kalfoss \& Owe, 20I5). This can be useful for nurses to improve their performance in providing nursing care (Faizin, Fitryasari, Wahyuni, \& Nursalam, 2020). The importance of leadership participation, communication, relationships among nurses and other professions also has an influence on nurse performance (Bainbridge \& Nasmith, 20II; Rosenstein \& O'Daniel, 2008; Shalala et al., 20II; West et al., 20I5). Increasing QNWL can make nurses more confident and able to work optimally. QNWL is a multi-dimensional concept that includes the domains (a) work life-home life, (b) work design, (c) work context, and (d) work world (Viselita et al., 2019). This includes all aspects of a nurse's life, both directly and indirectly focusing on the quality of her work.

The QNWL-based caring model can improve individual, social and environment and also administrative factors, which will impact the nurse performance. Seven indicators can have a vital role in improving individual factors, namely, age, gender, marital status, latest education, clinical level (career path), length of work, income. First, individual factor of nurses influencing the nurse's performance is education (Pujiyanto, Suprihati, Nursalam, \& Ediyati, 2017). This is in line with research in Jordan and Turkey where there is an effect of nurse education on improving nurse performance (Sirin \& Sokmen, 2015; Suleiman et al., 2019). The higher the level of education of a nurse, the higher the critical thinking, mature logic and can systematically improve the quality of work. A nurse with a higher level of education will think critically and more maturely than a diploma graduate. Education affects performance whereby nurses with higher education levels have more insight and knowledge. The caring aspect will also be explored as an important behavior and can be applied to improve nurse performance.
Women are stated to have a higher quality of working life with an average age of 26-35 years.

Length of work is also one of the factors that can affect the performance of nurses where a long experience will shape positive work behavior in nurses. Someone who already has extensive work experience can provide good performance by completing work on time, providing services in accordance with service standards, and having a positive impact on their work environment. When a nurse understands their duties correctly, it can benefit patients by improving the quality of their work. Work experience can provide benefits in the services that nurses provide to patients. The nurse will better understand the patient's needs and expectations so that they can provide assistance more quickly and accurately. Previous research has also shown that nursing care is influenced by nurses' work experience (Al-Tannir, 2018; Kaddourah, AbuShaheen, \& Al-Tannir, 2018; Viselita et al., 2019;Viselita, Handiyani, \& Pujasari, 2019). Nurses can provide appropriate care so as to increase patient confidence in nurses. Salary is the next factor that can improve nurse performance. An equal and commensurate salary given to nurses can increase the work motivation of nurses to provide the best performance; this has been supported by previous research (Kurtzman et al., 20II; McHugh \& Ma, 20I4; Platis, Reklitis, \& Zimeras, 20I5). Salaries that are not commensurate can hinder the quality of the work of nurses by decreasing and not maximizing performance (Winasih, Nursalam, \& Kurniawati, 20I5).

Meaning influences social and environment. For nurses, organizational communication is a process that provides benefits for improving employee performance. This study is in accordance with previous research conducted to determine the relationship between organizational communication and the performance of nurses (Kieft, de Brouwer, Francke, \& Delnoij, 20I4). Performance as a result of individual or group activities in an organization is an important thing that shows the successful implementation of the management system. Interaction in organizations requires coordination in various ways through communication so that individuals or groups in the organization become integrated parts to achieve one goal. Organizational communication is the glue of 
togetherness in the organization to achieve goals, coordinate organizational activities, and direct the behavior that the organization expects. Organizational communication that occurs effectively will make it easier for nurses to pay attention to things that are prioritized in the organization (Merlino, 2017; Rosenstein \& O'Daniel, 2008). Nurses can achieve workrelated goals through collaboration and effective communication with colleagues. Research shows a significant relationship between the head nurse's interpersonal communication and the job satisfaction of nurses (Dehaghani, Akhormeh, \& Mehrabi, 20I2). Weak organizational communication that occurs in nursing services can be an obstacle to achieving organizational goals in accordance with the established vision. Weak communication illustrates that communication has not occurred effectively; namely, the receipt of messages or information has not been accompanied by feedback from the recipient of the message.

Leadership can improve nurse performance. Nursing leadership behavior has been found to affect the ability of nurses to exceed the expectations of their superiors in meeting organizational goals (Ibrahim, El Sayed, Attala, \& Elmezin, 20I6). Nursing performance is associated with patient outcomes, and nursing leadership styles have an impact on meeting organizational goals (Cummings et al., 2010). However, several studies have investigated which leadership factors are considered by nurses themselves to influence their motivation to perform well and achieve organizational goals under increasing demands (Whitby, 2018). A systematic review is designed to gather evidence about the relationship between leadership and nurse performance from a nurse's perspective in order to understand the role of leadership in performance motivation. Based on a review of the literature, it is evident that limited research focuses on what nurses perceive to be their motivation to perform well, including whether the nursing leadership style is a factor in individual performance, among the various theories of nursing leadership today, in relation to positive employee performance and the theory of emotionally intelligent leadership (Brady \& Cummings, 2010; Sfantou et al., 2017). Nurse leaders must have the ability to influence staff and promote thoughts and actions that will lead to achieving the organization's goals, such as positive patient outcomes. This paper thus has the potential to provide healthcare organizations, particularly nurse managers and nurse leaders, with evidence-based knowledge of what motivates nurses to meet organizational goals of excellence in patient care, and further what leadership skills are needed to facilitate this.

The findings related to development of a QNWL to improve nurse performance demonstrated that QNWL based on caring positively influenced nurse performance. QNWL is something that requires attention in regard to the human resource management approach. There are many nursing facilities in the workplace that do not support nurses in carrying out their duties. Thus, the goal of QNWL is designed to achieve optimal nurse performance. The nurses in this study reported an increase in workload, resulting in fatigue, and yet still had energy after work.

QNWL based on caring promotes peran perawat yang sangat penting dalam hal profesionalitas kerja. Penerapan caring dalam QNWL memberikan staf mechanical thinking and encourages problem solving. In the work design dimension, nurses reported that their workload is heavy, and felt that there were inadequate nurses in the work setting. Furthermore, the majority of nurses were not satisfied with their job and they felt that they do not provide good quality patient care. This was found consistent with the findings of some previous studies which concluded that nurses' workload was heavy, and a majority of nurses were unable to complete their work in the time available (Akter, Akkadechanunt, Chontawan, \& Klunklin, 2018; Alharbi, Alahmadi, Alali, \& Alsaedi, 2019; Almalki, FitzGerald, \& Clark, 20I2; Suresh, 20I3). So, to overcome this, a new behavior pattern was formed with caring behavior toward nurses as a solution to overcome communication problems with poor patients. As has been researched, this study shows that incorporating aspects of good relationships, such as understanding, the presence of nurses physically and psychologically (empathy), helping, providing support, and trust, can increase the commitment and responsibility of a nurse and can increase work design to be better. 
In the work context dimension, the current study revealed that about half of the nurses were able to communicate with the nurse manager, receive feedback on their performance from the nurse manager, work within a team, feel respected by physicians, and were able to communicate with the other therapists in the unit, and felt they belonged to the workplace. These results are consistent with previous studies which stated that half of the sample was able to communicate with nurse manager/supervisor, and had adequate supervision by nurse supervisors (Nursalam, Fardiana, Asmoro, Fadhillah, \& Efendi, 2018; Winasih et al., 2015). In contrast, the results of the current study were found inconsistent with other studies which concluded that few nurses felt respected by the upper management, and were able to participate in decisions (Akter et al., 20।8; Suleiman et al., 20l9).

In the work world dimension, the respondents of the current study think that society has a negative image of nurses, that they do not receive adequate salary in comparison to the job market and their job impacts the lives of patients/families. The findings of this study are consistent with study (Karimi - Shahanjarini et al., 2019; Nursalam, Fibriansari, et al., 2018b) which emphasized that people think of nurses as assistants to the physicians, and many physicians also regard nurses only as their helpers and do not consider them as specialists in the art of caring. Furthermore, nurses felt that poor public image of nursing may affect not only their recruitment, but also their attitudes towards work ( Gunawan, Aungsuroch, Sukarna, \& Efendi, 2018; Kaur Pushpinder \& Rawat, 2017).

This study highlights the opportunities to create more perfect nursing care for patients. In other words, the opportunity for hospital nurses must be able to create a suitable quality of work while still providing the identity of a nurse, namely caring behavior. QNWL must be created through communication, patterns of relationships between caregivers and patients, with peers, other professions, leadership, and the environment (support system). Communication among nurses at all levels is important. Nurses must be aware of challenges that may affect their performance and be able to find solutions to problems in order to improve the status of quality work and carry out nursing care perfectly.

\section{CONCLUSION}

The model development in this research is a form of developing the dimension quality of work life of nurses which is integrated with Swanson's caring theory, whereby each dimension, such as work dimension and work content, is integrated with aspects of caring behavior, namely, good relationships such as understanding, the presence of nurses physically and psychologically (empathy), helping, providing support, and trust, which can increase the commitment and responsibility of a nurse. The evaluation of the QNWL model based on caring was influenced by some factors, including individual factors (age, sex, marital, education, clinical level, length of work, income), social and environmental factors (communication, leadership, and relationships between nurses), between departments, between professions, environment) and administrative factors (organizational policies, occupational health and safety, and salaries).

\section{Acknowledgement}

We would like to thank for all participants whom joined this research.

\section{Conflict of Interest}

All the authors have no conflict of interest related to the study.

\section{REFERENCES}

A. Aziz Alimul Hidayat, Stefanus Supriyanto, N. (20I5). Model sistem manajemen mutu berdasarkan kriteria malcolm baldrige pada pendidikan keperawatan di kota surabaya. Jurnal Ners Vol. 10 No. I April 2015: 165-174, 10, 165-174.

Abdul Muhith, N. N. (20I2). Quality of Nursing care Based on Analysis of Nursing Performance and Nurse and Patient Satisfaction. Jurnal Ners, 7(I), 47-55. https://doi.org/http://dx.doi.org//0.20473/ jn.v7il.3998

Akter, N., Akkadechanunt, T., Chontawan, R., \& Klunklin, A. (20I8). Factors predicting quality of work life among nurses in tertiary-level hospitals, Bangladesh. 
International Nursing Review, 65(2), 182189.

Alharbi, M. F., Alahmadi, B. A., Alali, M., \& Alsaedi, S. (2019). Quality of nursing work life among hospital nurses in Saudi Arabia: A cross-sectional study. Journal of Nursing Management, 27(8), I722-1730.

Almalki, M. J., FitzGerald, G., \& Clark, M. (20I2). Quality of work life among primary health care nurses in the Jazan region, Saudi Arabia: a cross-sectional study. Human Resources for Health, IO(I), 30.

https://doi.org/https://doi.org//0.1 186/14 78-4491-10-30

Amalina, S. F., Rachmawaty, R., Ilkafah, I., \& Erfina, E. (2020). Patient experiences of nurse caring behaviors based on Swanson's theory in Indonesian hospital. Enfermería Clínica, 30, 332-336. https://doi.org//0.1016/j.enfcli.2019.07.I I 3

Brady, P. G., \& Cummings, G. G. (20I0). The influence of nursing leadership on nurse performance: a systematic literature review. Journal of Nursing Management, I8(4), 425-439. https://doi.org/I0.1 I I I/j. I3652834.2010.01100.x

Chana, N., Kennedy, P., \& Chessell, Z. J. (20I5). Nursing staffs' emotional well-being and caring behaviours. Journal of Clinical Nursing, $\quad$ 24(I9-20), 2835-2848. https://doi.org/https://doi.org/10.1 I I I/joc n. I289|

Cummings, G. G., MacGregor, T., Davey, M., Lee, H., Wong, C. A., Lo, E., ... Stafford, E. (20I0). Leadership styles and outcome patterns for the nursing workforce and work environment: a systematic review. International Journal of Nursing Studies, 47(3), 363-385.

Dehaghani, A. R., Akhormeh, K. A., \& Mehrabi, T. (20/2). Assessing the effectiveness of interpersonal communication skills training on job satisfaction among nurses in Al-Zahra Hospital of Isfahan, Iran. Iranian Journal of Nursing and Midwifery Research, I7(4), 290.

Faizin, R., Fitryasari, R., Wahyuni, E. D., \& Nursalam, N. (2020). Nurse's Individual Factors May Predict Quality of Nursing Work Life (Qnwl) in Clinical Setting.
International Journal of Psychosocial Rehabilitation, 24(7).

Ferreira, M. R. S. do C., \& Martins, J. J. P. A. (20I4). Study of adaptation and validation of the Practice environment scale of the nursing work index for the Portuguese reality. Revista $\mathrm{Da}$ Escola de Enfermagem Da USP, 48(4), 69I-698.

Gunawan, J., Aungsuroch, Y., Sukarna, A., \& Efendi, F. (2018). The image of nursing as perceived by nurses: A phenomenological study. Nursing and Midwifery Studies, 7(4), 180.

Gunawan, N. P. I. N., Hariyati, R. T. S., \& Gayatri, D. (20/9). Motivation as a factor affecting nurse performance in Regional General Hospitals: A factors analysis. Enfermeria Clinica, 29, 5I5-520.

Ibrahim, S. A. E., El Sayed, R. I., Attala, M. M., \& Elmezin, N. K. (2016). Relationship between head nurses' leadership styles and staff nurses' job performance. IOSR Journal of Nursing and Science, 5(I), 66-74. https://doi.org/I0.9790//959-05 I 46674

Kaddourah, B., Abu-Shaheen, A. K., \& AlTannir, M. (20I8). Quality of nursing work life and turnover intention among nurses of tertiary care hospitals in Riyadh: a cross-sectional survey. BMC Nursing, I 7(I),

43. https://doi.org//0.1016/j.enfcli.2019.06.00 I Acceso a texto completo

Karimi-Shahanjarini, A., Shakibazadeh, E., Rashidian, A., Hajimiri, K., Glenton, C., Noyes, J., ... Colvin, C. J. (2019). Barriers and facilitators to the implementation of doctor-nurse substitution strategies in primary care: a qualitative evidence synthesis. Cochrane Database of Systematic Reviews, (4).

Kaur Pushpinder, M. S., \& Rawat, H. (2017). Impact of Self Perceived Public Image of Nursing on Nurses Work Behavior. International Journal, 3(2), 7.

Kieft, R. A. M. M., de Brouwer, B. B. J. M., Francke, A. L., \& Delnoij, D. M. J. (20|4). How nurses and their work environment affect patient experiences of the quality of care: a qualitative study. BMC Health Services Research, 14(I), 1-10. https://doi.org/I0.1 I86/1472-6963-14249

Kurtzman, E. T., O'Leary, D., Sheingold, B. H., Devers, K. J., Dawson, E. M., \& Johnson, J. 
E. (20II). Performance-based payment incentives increase burden and blame for hospital nurses. Health Affairs, 30(2), 2II218.

https://doi.org/https://doi.org//0.1377/hlt haff.2010.0573

McHugh, M. D., \& Ma, C. (2014). Wage, work environment, and staffing: effects on nurse outcomes. Policy, Politics, \& Nursing Practice, 15(3-4), 72-80. https://doi.org//0.1/77//527/544/45468 68

Merlino, J. (2017). Communication: A critical healthcare competency. Patient Saf. Qual. HealthCare.

Momeni, B., Shafipour, V., Esmaeili, R., \& Yazdani Charati, J. (20/6). The relationship between the quality of work life and sleep in nurses at the intensive care units of teaching hospitals in Mazandaran, Iran. Journal of Nursing and Midwifery Sciences, 3(I), 28-34.

Nursalam. (20I8). Manajemen Keperawatan Aplikasi dalam Praktik Keperawatan Profesional (5th ed.; P. Lestari, Ed.). Jakarta: Salemba Medika.

Nursalam. (2020). Metodologi Penelitian Ilmu Keperawatan: Pendekatan Praktis (5th ed). Jakarta: Salemba Medika.

Nursalam, Fibriansari, R. D., Yuwono, S. R., Hadi, M., Efendi, F., \& Bushy, A. (2018a). Development of an empowerment model for burnout syndrome and quality of nursing work life in Indonesia. International Journal of Nursing Sciences, 5(4), 390-395.

Nursalam, N., Fardiana, A., Asmoro, C. P., Fadhillah, H., \& Efendi, F. (20/8). The Correlation between the Quality of nursing Work life and Job Performance. Indian Journal of Public Health Research \& Development.

Nursalam, N., Fibriansari, R. D., Yuwono, S. R., Hadi, M., Efendi, F., \& Bushy, A. (2018b). Development of an empowerment model for burnout syndrome and quality of nursing work life in Indonesia. International Journal of Nursing Sciences, 5(4), 390-395. https://doi.org//0.1016/j.ijnss.2018.05.001

Oluma, A., \& Abadiga, M. (2020). Caring behavior and associated factors among nurses working in Jimma University specialized hospital, Oromia, Southwest Ethiopia, 2019. BMC Nursing, 19(I), I-7. https://doi.org/https://doi.org//0.1 I86/s 12 912-020-0407-2

Oshodi, T. O., Bruneau, B., Crockett, R., Kinchington, F., Nayar, S., \& West, E. (2019). The nursing work environment and quality of care: Content analysis of comments made by registered nurses responding to the Essentials of Magnetism II scale. Nursing Open.

Platis, C., Reklitis, P., \& Zimeras, S. (20I5). Relation between job satisfaction and job performance in healthcare services. Procedia-Social and Behavioral Sciences, I75(I), 480-487.

Pujiyanto, T. I., Suprihati, S., Nursalam, N., \& Ediyati, A. (2017). Improving Nursing Work Services through Development Model of Quality of Nursing Work Life. Journal Ners, I2(2), 2/2-2।8.

Rosenstein, A. H., \& O'Daniel, M. (2008). Professional communication and team collaboration. Patient Safety and Quality: An Evidence-Based Handbook for Nurses.

Sfantou, D. F., Laliotis, A., Patelarou, A. E., Sifaki-Pistolla, D., Matalliotakis, M., \& Patelarou, E. (2017). Importance of leadership style towards quality of care measures in healthcare settings: a systematic review. Healthcare, 5(4), 73. https://doi.org// 0.3390/healthcare504007 3

Sirin, M., \& Sokmen, S. M. (20I5). Quality of nursing work life scale: the psychometric evaluation of the Turkish version. International Journal of Caring Sciences, 8(3), 543.

Suleiman, K., Hijazi, Z., Al Kalaldeh, M., \& Sharour, L. A. (2019). Quality of nursing work life and related factors among emergency nurses in Jordan. Journal of Occupational Health, 6I(5), 398-406. https://doi.org// 0.1002/I348-9585.12068

Suresh, D. (2013). Quality of Nursing Work Life among nurses working in selected government and private hospitals in Thiruvananthapuram. Institute for Medical Sciences \& Technology Thiruvananthapuram: SCTIMST.

Terzioglu, F., Temel, S., \& Uslu Sahan, F. (2016). Factors affecting performance and productivity of nurses: professional attitude, organisational justice, organisational culture and mobbing. 
Journal of Nursing Management, 24(6), 735744.

Tri Ismu Pujiyanti, Suprihati Suprihati, N. N., \& Anastasia Ediyati. (20/6). Improving Nursing Work Services Through Development Model of Quality of Nursing Work Life. Jurnal Ners, II(I), 2I2-2I8. https://doi.org/doi: http://dx.doi.org// 0.20473/jn.v8il .3893

Viselita, F., Handiyani, H., \& Pujasari, H. (2019). Quality level of nursing work life and improvement interventions: Systematic review. Enfermeria Clinica. https://doi.org/DOI: 10.1016/j.enfcli.2019.06.00।

Vuković, M., Grozdenović, B. S., Stamatovićgajić, B., llić, M., \& Gajić, T. (2010). Development and Evaluation of the Nurse Quality of Communication with Patient Questionnaire. Srpski Arhiv Za Celokupno
Lekarstvo, (November 2015). https://doi.org/I0.2298/SARHI 002079V

Vveinhardt, J., \& Gulbovaite, E. (20I7). Models of congruence of personal and organizational values: how many points of contact are there between science and practice? Journal of Business Ethics, 145(I), ||$|-| 3 \mid$.

Whitby, P. (2018). Role of front-line nurse leadership in improving care. Nursing Standard, 33(8). https://doi.org/I0.7748/ns.20I8.el I0I8

Winasih, R., Nursalam, N., \& Kurniawati, N. D. (20I5). Cultural Organization and Quality of Nursing Work Life on Nurses Performance and Job Satisfaction in Dr. Soetomo Hospital, Surabaya. Jurnal Ners, I0(2),

332-342. https://doi.org/http://dx.doi.org/ / 0.20473/ jn.v10i2.I403 